\title{
Elk Distributions Relative to Spring Normalized Difference Vegetation Index Values
}

\author{
Samuel T. Smallidge, ${ }^{1}$ Terrell T. Baker, ${ }^{1}$ Dawn VanLeeuwen, ${ }^{1}$ William R. Gould, ${ }^{2}$ \\ and Bruce C. Thompson ${ }^{3}$ \\ ${ }^{1}$ College of Agricultural, Consumer and Environmental Sciences, New Mexico State University, P.O. Box 30003, MSC 3AE, \\ Las Cruces, NM 88003, USA \\ ${ }^{2}$ University Statistics Center, New Mexico State University, P.O. Box 30003, MSC 3CQ, Las Cruces, NM 88003, USA \\ ${ }^{3}$ New Mexico Energy, Minerals and Natural Resources Department, 1220 South St. Francis Dr., Santa Fe, NM 87505, USA \\ Correspondence should be addressed to Samuel T. Smallidge, ssmallid@nmsu.edu
}

Received 3 September 2009; Accepted 9 April 2010

Academic Editor: Herman H. Shugart

Copyright (๑) 2010 Samuel T. Smallidge et al. This is an open access article distributed under the Creative Commons Attribution License, which permits unrestricted use, distribution, and reproduction in any medium, provided the original work is properly cited.

Rocky Mountain elk (Cervus elaphus) that winter near San Antonio Mountain in northern New Mexico provide important recreational and economic benefits while creating management challenges related to temporospatial variation in their spring movements. Our objective was to examine spring distributions of elk in relation to vegetative emergence as it progresses across the landscape as measured by remote sensing. Spring distributions of elk were closely associated with greater photosynthetic activity of spring vegetation in 2 of 3 years as determined using NDVI values derived from AVHRR datasets. Observed elk locations were up to $271 \%$ greater than expected in the category representing the most photosynthetic activity. This association was not observed when analyses at a finer geographic scale were conducted. Managers facing challenges involving human-wildlife interactions and land-use issues should consider environmental conditions that may influence variation in elk association with greener portions of the landscape.

\section{Introduction}

Rocky Mountain elk (Cervus elaphus) have been described as initiating seasonal movements in response to snow conditions [1,2], changes in photoperiod [3], and spring vegetation emergence or greenup $[1,3,4]$. While it is common belief among natural resources professionals and lay persons that elk follow greenup or receding snowline, most references of elk following spring greenup are anecdotal [5-8]. However, Sweeney [1] investigated elk movements in relation to snowline and greenup during spring, as well as in relation to calving behavior. He concluded that elk are associated with snowline, particularly when green vegetation was in close proximity. Snow depth and forage phenology are proximal stimuli for migration [4] with the ultimate driving force of ungulate migration evolving from spatial variability in quality, quantity, and availability of forage [9-11]. Another explanation for ungulate distributions includes reduced risk of predation [12-14], however, the interactions are complex and elk movements may not be linked to direct predation threats in all circumstances [15]. In this paper, we apply advances in remote sensing technologies to allow for a more explicit examination of elk distribution and movement in relation to spring vegetation phenology.

Elk migrate between seasonal home ranges following vegetation in early phenological stages from lowlands to alpine habitats, from southern to northern exposures, and from open- to closed-canopied areas to best exploit localized vegetative conditions $[5,16-19]$ resulting from ecological and climatic factors $[7,20]$. They are intermediate feeders [21] that may graze or browse depending on vegetation characteristics and time of year. A combination of food availability and weather provide the most likely explanation for timing and extent of most elk movements [3]. Through movement, elk may improve temporal variation in their fitness [22] by exploiting geographically variable vegetation 
conditions that enhance their overall body condition [2325 ] which is ultimately expressed through population performance [26]. Migration behavior provides a means for greater numbers of elk to be maintained on a landscape than continual use of a single area [3]. Green-up is thought to attract elk because of increased forage quality [17, 19, 27] during times of increased energy demand [24].

Green-up may be defined as onset of deciduous plant growth in early spring [28] or as, "onset of leafing" [29], or spring vegetation emergence. Greenwave is the progression of vegetation emergence across a landscape and represents an interaction of a complex set of integrated events influenced by biospheric and atmospheric feedbacks [28] operating at multiple spatial and temporal scales. Spring greenwave typically advances from lower to higher latitudes and from lower to higher elevations or below snowline on exposed south-facing slopes $[1,8]$.

Greenwave can be delineated using remote sensing technologies. National Oceanic and Atmospheric Administration (NOAA) Advanced Very High Resolution Radiometer (AVHRR) satellite-derived datasets have been used to calculate a normalized difference vegetation index (NDVI) ratio using near infrared (NIR) and visible (VIS) wavelength measurements [30-32]. NDVI is a numerical index of the presence and activity of vegetation. Multitemporal NDVI datasets have been used to accurately characterize vegetation phenological patterns $[29,32-37]$ spatially and temporally. Goward et al. [32] concluded that NDVI values based on AVHRR data corresponded with North American vegetation phenological patterns. NDVI datasets also have been useful for regional [36-39] and subregional $[39,40]$ scaled characterizations of vegetation phenological patterns. They have been reliably associated with peak faecal crude protein in mountain ungulates [41]. NDVI values are closely associated with cumulative precipitation measures and may respond to individual precipitation events $[40,42,43]$ during the growing season.

Elk traverse private grazing lands often associated with resource conflicts between livestock and elk. Although potential for exploitative competition is more probable in late summer [44], forage use during spring can negatively impact subsequent use by livestock [45]. Variation in elk distributions may contribute to existing resource conflicts or lead to resource conflicts in areas where previously absent. Understanding the nature and timing of spring elk distributions in relation to greenwave will aid in managing for multiple uses in areas where elk presence may cause challenges with other interests. Our objective was to investigate the relationship between greenwave and elk spring distribution patterns by examining the extent to which distribution of elk migrating in spring was associated with landscape level photosynthetic activity of vegetation.

\section{Study Area}

Research was conducted in the vicinity of San Antonio Mountain (3,325 m max elevation, latitude N $36^{\circ} 52^{\prime} 00^{\prime \prime}$, and longitude $\mathrm{W} 106^{\circ} 00^{\prime} 00^{\prime \prime}$ ) approximately $30 \mathrm{~km}$ equidistant northwest of Tres Piedras, New Mexico and southwest of Antonito, Colorado (Figure 1). Canyons, elevated plains, simple slopes, scarps, hills, mesas, subalpine and alpine meadows, and mountains are common landscape features. Elevations range from approximately $2,200 \mathrm{~m}$ to approximately 3,660 m in the San Juan Mountains of New Mexico and nearly 4,270 $\mathrm{m}$ in the San Juan Mountains of Colorado. Soils are described as loamy-skeletal, cobbly-loam, gravellysandy loam, and stony, with parent material derived from andesite, shale, and basalt [46]. Annual precipitation for the area ranges from 250 to $>900 \mathrm{~mm}$, annual snowfall ranges from 50 to $>200 \mathrm{~cm}$ [47]. Mean minimum temperature ranges from $-18^{\circ} \mathrm{C}$ to $-11^{\circ} \mathrm{C}$ in January to a mean maximum temperature range of $24^{\circ} \mathrm{C}$ to $33^{\circ} \mathrm{C}$ in July.

Vegetation ranges from Great Basin scrub pinyon-juniper (Pinus spp.-Juniperus spp.) woodland at lower elevations and gentler slopes to spruce-fir (Picea spp.-Abies spp.) forest and montane grassland at highest elevations [48]. Specifically, the Great Basin Conifer Woodlands were dominated by pinyonjuniper at elevations up to $2,300 \mathrm{~m}$. Within these regions were areas characterized as Great Basin Grasslands [49]. Higher regions were defined as Rocky Mountain Subalpine Forest consisting of Engelmann spruce (Picea engelmannii) and subalpine fir (Abies lasiocarpa) at 2,438-3,659 m. Rocky Mountain Montane Conifer Forests at 2,200-3,050 m were dominated by ponderosa pine (Pinus ponderosa) at lower elevations grading into stands of Douglas-fir (Pseudotsuga menziesii), aspen (Populus tremuloides), white fir (Abies concolor), and limber pine (Pinus flexilis) at higher elevations [50].

\section{Methods}

One-hundred and ten elk were captured using a netgun fired from a helicopter [51] to deploy radiocollars on elk during the 1998-1999 $(n=75)$ and 1999-2000 $(n=35)$ winter seasons. Capture efforts during winter 1999-2000 attempted to account for temporal variation in origins or composition of the San Antonio elk population and to replace radiocollared individuals that were lost to mortality or collar failure. Animal care and handling guidelines were approved by the Institutional Animal Care and Use Committee at New Mexico State University. Radiocollars (Telonics, MOD500, Mesa, AZ) were hermetically sealed and encased in $7.6 \mathrm{~cm}$ white collar belting and electrical resin and included a unique frequency in the 150.000 to $151.999 \mathrm{MHz}$ range and a 24-hour mortality switch. Radiocollars were proportionally distributed among easily identifiable strata based on number and sex of elk seen during precapture reconnaissance flights to increase probability of sampling from subpopulations representing different summer range origins. Twenty percent of all collars were deployed on adult bull elk to ensure proportional representation of bulls in the sample. Radiocollared elk were located at 5- to 14-day intervals when elk were migrating between seasonal ranges. Onset of seasonal migrations for each year was determined by plotting the percentage of elk on Winter Range (Figure 2) by aerial tracking flight date and systematically examining movement 

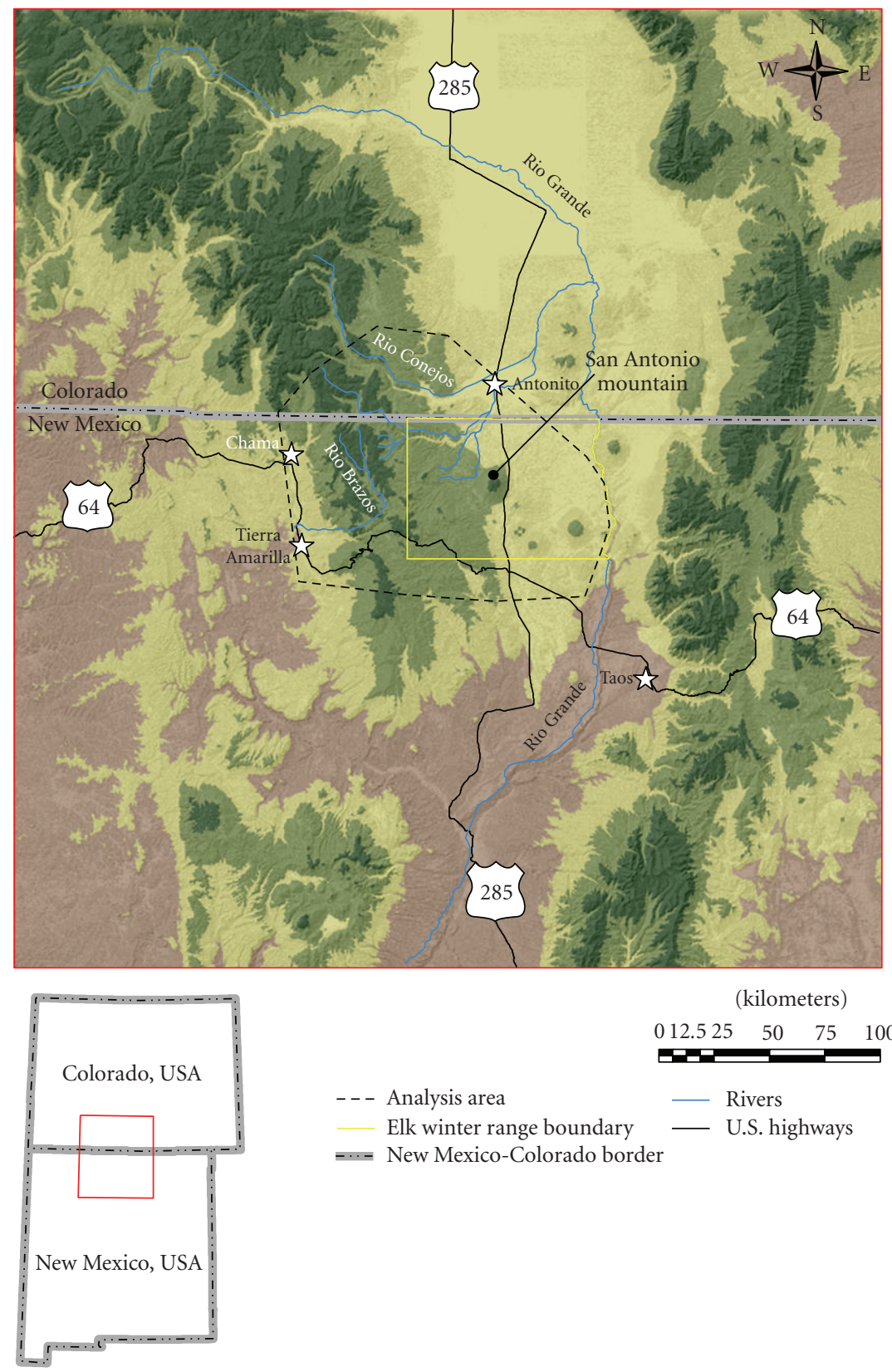

(kilometers)

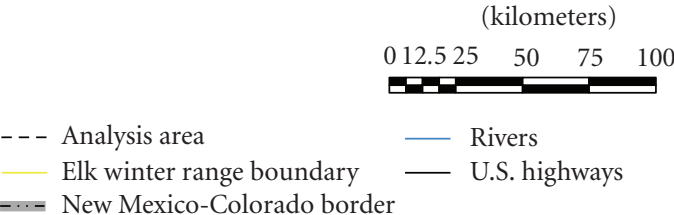

-... New Mexico-Colorado border

FIgUre 1: Geographic location of San Antonio Mountain, New Mexico, U.S.A. elk research study area associated with San Antonio Mountain elk research conducted from December 1998 through December 2001.

patterns a posteriori [52]. Harris et al. [53] suggests that using knowledge of animal behavior to determine time frames for estimating seasonal use areas is biologically reasonable. A nominal $1 \mathrm{~km}$ error distance was associated with aerial locations of elk [54].

We estimated vegetation greenness, as indicated by NDVI values, using postprocessed NOAA AVHRR multitemporal datasets $[32,34,36,37]$. These datasets have a nominal $1-\mathrm{km}^{2}$ pixel resolution and were obtained for March through June 1999, 2000, and 2001. Similar elk location error and AVHRR pixel resolution allowed for meaningful analyses. Datasets were comprised of Maximum Value Composite [55] images created by selecting the maximum pixel value of each pixel recorded during a 14-day composite date range (U.S.D.I. U.S.G.S. - Earth Resources Observation and Science (EROS) Data Center, 2003). Maximum Value Composite procedures reduce anomalous or erroneous NDVI values, minimize cloud contamination, reduce off-nadir viewing effects, minimize sun-angle and shadow effects, and minimize aerosol and water-vapor effects [55].

NDVI values indicate the relative photosynthetic activity of surface vegetation based on the near-infrared (NIR) and visible (VIS) reflectance values $[32,56]$ and are calculated by determining the ratio (NIR-VIS)/(NIR+VIS). Theoretically, 


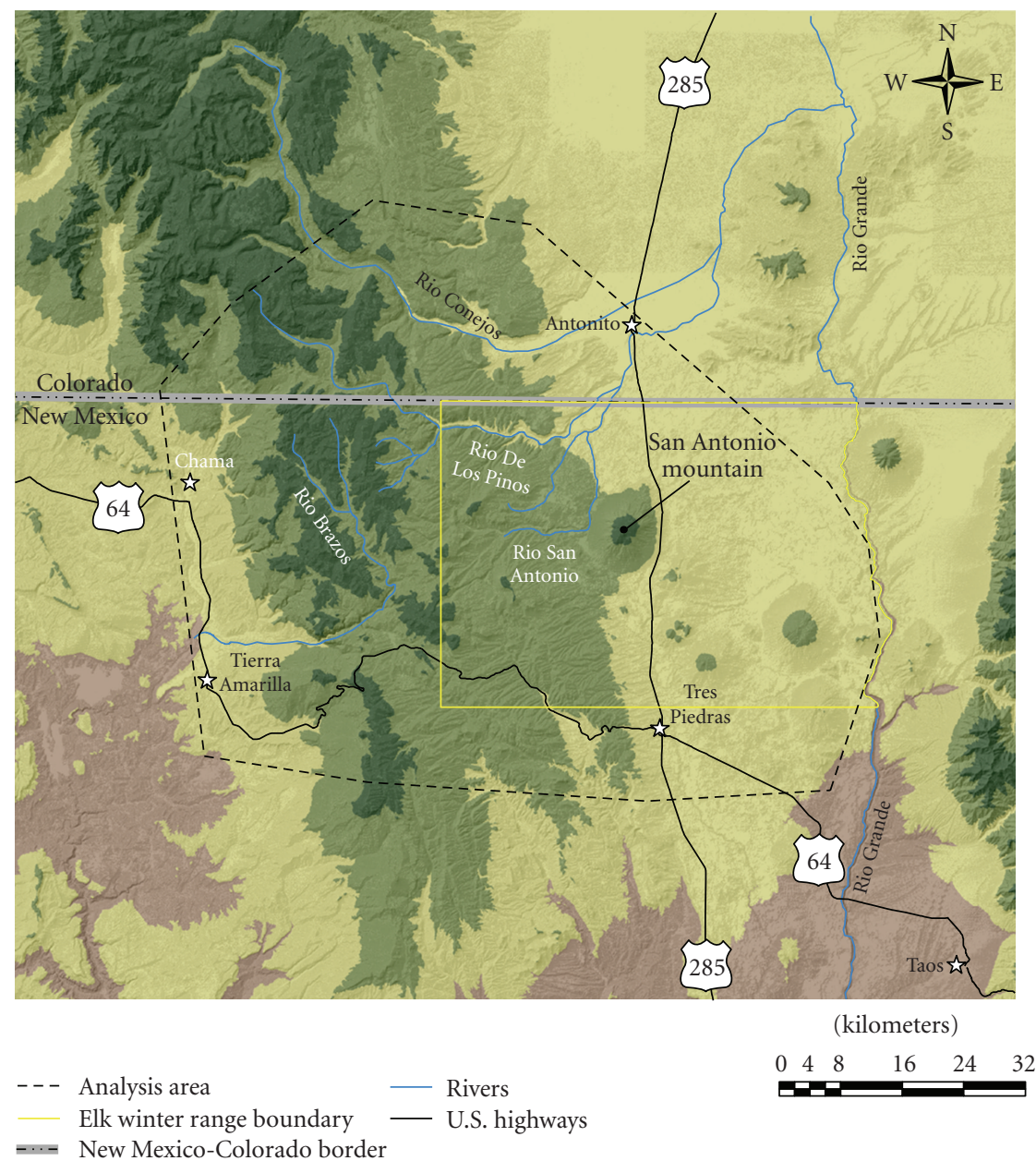

Figure 2: Winter Range and a 100\% Minimum Convex Polygon, Analysis Area, representing the full spatial distribution, of all elk locations that wintered on, or near, San Antonio Mountain, New Mexico, 1998-2001.

NDVI values range from -1.0 to 1.0 and represent increasing levels of photosynthetic activity with increasing value. In practice, these values typically range from -0.1 to 0.64 [57] or as high as 0.7 [32]. NDVI data were rescaled by EROS and range from 0 to 200 , with 0 equal to $-1.0,100$ equal to 0 , and 200 equal to 1.0 [56]. Although a specific threshold determining onset of green-up has been disputed [35], several studies have demonstrated rescaled NDVI values of approximately 110 indicate a high probability of photosynthetic activity [32, 33, 40, 57-59].

We delineated the maximum observed annual areal extent of herd movements using a geographic information system (GIS), ArcView 3.2a [60], to create a Minimum Convex Polygon (MCP, 61, Figure 2, Analysis Area) around pooled locations of all radiocollared elk, excluding emigrants that left the population and did not return [54]. The Analysis Area boundary was defined by this 100\% MCP of all elk locations [61] with an arbitrarily selected $5-\mathrm{km}$ buffer to minimize boundary effects when conducting image analysis and processing. Using computer programs IMAGINE 8.6 [62], ArcView 3.3 [63], and ArcGIS 9.0 [64], we pooled elk location dates to match the date ranges of AVHRR Maximum
Value Composite images; hereafter referred to as an image. Mean NDVI values for each elk location were computed using a $3 \times 3$ cell matrix ( 9 pixel) operation centered on the pixel in which the elk location was recorded. Calculating mean NDVI minimized the potential for anomalous pixel values and elk point location error.

We compared NDVI values of the Analysis Area with mean NDVI values associated with observed elk locations. NDVI values were placed in categories representing various levels of photosynthetic activities. Background null values were excluded from analysis. NDVI values from 1 to 100 represent nonvegetative nonphotosynthetically active surfaces including snow, water, clouds, and barren lands $[32,56,57]$. Values ranging from 101 to 109 represent vegetated nonphotosynthetically active surfaces [58]. A nonphotosynthetically active surface (NPAS) category was created to represent both nonvegetated and vegetated surfaces ranging in value from 1 to 109. Photosynthetically active surfaces (PASs) were classified into 3 ordinal categories representing increasing NDVI greenness value ranges from 110 to 129 (PAS-1), 130 to 149 (PAS-2), and 150 to 200 (PAS-3). These categories do not represent precise breaks in vegetation characteristics or 
TABLE 1: Observed (O) and expected (E) frequencies, proportion of AVHRR image area by category and date, and Chi-square values of San Antonio Mountain, New Mexico elk locations and concurrent Analysis Area $\left(5,912 \mathrm{~km}^{2}\right)$ AVHRR image NDVI values classified into nonphotosynthetically active surface (NPAS) and photosynthetically active surface (PAS) categories for 1999, 2000 , and 2001.

\begin{tabular}{|c|c|c|c|c|c|c|c|c|c|c|c|c|c|c|c|c|c|}
\hline \multirow[t]{2}{*}{ Year } & \multirow[t]{2}{*}{$\begin{array}{l}\text { AVHRR Image } \\
\text { Date Range }\end{array}$} & \multirow{2}{*}{$\begin{array}{l}\text { No. } \\
\text { Elk } \\
\text { Obs. }\end{array}$} & \multicolumn{2}{|c|}{ NPAS } & \multirow[t]{2}{*}{ NPAS Area } & \multicolumn{2}{|c|}{ PAS-1 } & \multirow[t]{2}{*}{$\begin{array}{l}\text { PAS-1 } \\
\text { Area }\end{array}$} & \multicolumn{2}{|c|}{ PAS-2 } & \multirow[t]{2}{*}{$\begin{array}{l}\text { PAS-2 } \\
\text { Area }\end{array}$} & \multicolumn{2}{|c|}{ PAS-3 } & \multirow[t]{2}{*}{$\begin{array}{l}\text { PAS-3 } \\
\text { Area }\end{array}$} & \multirow[t]{2}{*}{$\chi^{2}$} & \multirow[t]{2}{*}{ df } & \multirow[t]{2}{*}{$P$-value } \\
\hline & & & $\mathrm{O}$ & $\mathrm{E}$ & & $\mathrm{O}$ & $\mathrm{E}$ & & $\mathrm{O}$ & $\mathrm{E}$ & & $\mathrm{O}$ & $\mathrm{E}$ & & & & \\
\hline \multirow{6}{*}{1999} & $26 \mathrm{Mar}-8 \mathrm{Apr}$ & 93 & & 0.4 & 0.004 & 13 & 30 & 0.32 & 70 & 55 & 0.59 & 10 & 8 & 0.09 & 14.244 & 3 & .003 \\
\hline & 9 Apr-22 Apr & 124 & 1 & 2 & 0.01 & 25 & 39 & 0.32 & 84 & 69 & 0.56 & 14 & 14 & 0.11 & 8.622 & 3 & .035 \\
\hline & 23 Apr-6 May & 127 & 2 & 6 & 0.05 & 35 & 39 & 0.31 & 76 & 73 & 0.57 & 14 & 10 & 0.08 & 5.232 & 3 & .156 \\
\hline & 7 May-20 May & 47 & & & & 11 & 12 & 0.25 & 28 & 29 & 0.63 & 8 & 5 & 0.11 & 1.705 & 2 & .636 \\
\hline & 21 May-3 Jun & 126 & 4 & 5 & 0.04 & 79 & 64 & 0.51 & 43 & 54 & 0.43 & & 3 & 0.02 & 8.651 & 3 & .034 \\
\hline & 4 Jun-17 Jun & 40 & & & & & 0.4 & 0.01 & 2 & 20 & 0.50 & 38 & 20 & 0.49 & 33.492 & 2 & $<.001$ \\
\hline \multirow{6}{*}{2000} & 25 Mar-7 Apr & 79 & & 5 & 0.06 & 12 & 37 & 0.46 & 47 & 30 & 0.37 & 20 & 8 & 0.10 & 50.072 & 3 & $<.001$ \\
\hline & 8 Apr-21 Apr & 66 & & 1 & 0.02 & 8 & 26 & 0.39 & 32 & 32 & 0.49 & 26 & 7 & 0.10 & 68.745 & 3 & $<.001$ \\
\hline & 22 Apr-5 May & 145 & & & & 8 & 37 & 0.25 & 96 & 89 & 0.61 & 41 & 20 & 0.14 & 45.807 & 2 & $<.001$ \\
\hline & 6 May-19 May & 112 & & & & 6 & 21 & 0.18 & 52 & 60 & 0.54 & 54 & 31 & 0.28 & 28.529 & 2 & $<.001$ \\
\hline & 20 May-3 Jun & 77 & & & & 3 & 15 & 0.20 & 6 & 28 & 0.37 & 68 & 33 & 0.43 & 64.567 & 2 & $<.001$ \\
\hline & 4 Jun-16 Jun & 121 & & & & 2 & 32 & 0.27 & 9 & 39 & 0.33 & 110 & 49 & 0.41 & 125.681 & 2 & $<.001$ \\
\hline \multirow{5}{*}{2001} & 6 Apr-19 Apr & 31 & & 4 & 0.11 & 8 & 15 & 0.48 & 23 & 12 & 0.39 & & 0.5 & 0.02 & 17.281 & 3 & $<.001$ \\
\hline & 20 Apr-3 May & 117 & 9 & 8 & 0.07 & 29 & 52 & 0.44 & 79 & 56 & 0.48 & & 1 & 0.01 & 21.082 & 3 & $<.001$ \\
\hline & 4 May-17 May & 62 & & 0.3 & 0.00 & 3 & 18 & 0.29 & 32 & 32 & 0.52 & 27 & 12 & 0.19 & 31.801 & 3 & $<.001$ \\
\hline & 18 May-31 May & 119 & & & & 1 & 31 & 0.26 & 61 & 56 & 0.47 & 57 & 32 & 0.27 & 50.185 & 2 & $<.001$ \\
\hline & 15 Jun-28 Jun & 58 & & & & & 14 & 0.24 & 7 & 17 & 0.29 & 51 & 27 & 0.47 & 40.526 & 2 & $<.001$ \\
\hline
\end{tabular}

landscape features that influence NDVI values. They represent a gradation from surfaces incapable of photosynthetic activity to surfaces capable of increasing photosynthetic potential as delimited by vegetation aggregation.

A Chi-square analysis was conducted for each year by combining NDVI value categories into nonphotosynthetic and photosynthetic categories to test for differences between frequency of elk observations and the proportion of the Analysis Area each category represented. Frequency of elk observations for each of 4 NDVI categories were recorded and Chi-square values were calculated based on the proportion each NDVI category comprised in the concurrent AVHRR date composite image [65]. We partitioned the experiment-wise error rate $\left(\alpha_{e}=0.05\right)$ using Bonferroni's adjustment [66] for each set of comparisons. A few expected frequencies for the NPAS category were much smaller than conventionally suggested [67]; therefore, when a significant test included cells with expected frequencies less than 1 , the chi-squared values associated with small expected frequencies were removed to assess sensitivity of the significance. We report chi-square contributions of individual categories to identify those categories most substantially contributing to the total chi-square statistic.

A second Chi-square analysis was conducted to determine if elk spring distributions were associated with smaller areas within the larger Analysis Area. Small analysis areas were delineated using 100\% MCP derived for each set of elk locations concurrent with the time period for each AVHRR image. The proportion of the small analysis area each NDVI category represented was made for individual images to determine if elk were selecting greener locations based on the smaller area. This represents a higher order habitat selection analysis [68] relative to the Analysis Area. Johnson's [68] hierarchy of habitat selection identified four levels based on an increasing geographic scale which necessitates that higher order habitat selection be conditional to the lower order habitats. In this case, elk locations that fall within the time period of the AVHRR image define the small analysis area and represent only a fraction of the larger Analysis Area. NDVI classification criteria and Chi-square analyses previously described were used for this analysis.

\section{Results}

Distribution of San Antonio elk locations on nonphotosynthetically active surfaces (NPASs) and photosynthetically active surfaces (PASs) differed greatly from expected distributions in 2 of the 3 years examined (Table 1). In 1999, elk distributions were associated with greener areas during 26 March-8 April $\left(P=.003, \chi^{2}=14.2\right.$, DF 3$)$ and 4-17 June $\left(P<.001, \chi^{2}=33.5\right.$, DF 2$)$. PAS-1 (Table 1$)$ for 26 March8 April image recorded $57 \%$ fewer elk observations than expected, while $27 \%$ more observations were made in PAS2 than expected. Similarly for the 4-17 June time interval, PAS-2 areas had 90\% fewer elk observations than expected while PAS-3 areas had 90\% more elk locations than expected (Table 1). The 4 intermediate date intervals did not exhibit differences between observed and expected values. 
TABLE 2: Observed (O) and expected (E) frequencies, proportion of AVHRR image area by category and date, and Chi-square values of San Antonio Mountain, New Mexico elk locations and AVHRR image NDVI values using corresponding elk location Minimum Convex Polygon (MCP) reference areas classified into nonphotosynthetically active surface (NPAS) and photosynthetically active surface (PAS) categories for 1999, 2000, and 2001.

\begin{tabular}{|c|c|c|c|c|c|c|c|c|c|c|c|c|c|c|c|c|c|c|}
\hline \multirow[t]{2}{*}{ Year } & \multirow[t]{2}{*}{$\begin{array}{l}\text { AVHRR Image } \\
\text { Date Range }\end{array}$} & \multirow{2}{*}{$\begin{array}{l}\text { No. } \\
\text { Elk } \\
\text { Obs. }\end{array}$} & \multirow{2}{*}{$\begin{array}{c}\text { MCP } \\
\text { Area } \\
\left(\mathrm{km}^{2}\right)\end{array}$} & \multicolumn{2}{|c|}{ NPAS } & \multirow[t]{2}{*}{$\begin{array}{c}\text { NPAS } \\
\text { Area }\end{array}$} & \multicolumn{2}{|c|}{ PAS-1 } & \multirow[t]{2}{*}{$\begin{array}{l}\text { PAS1 } \\
\text { Area }\end{array}$} & \multicolumn{2}{|c|}{ PAS-2 } & \multirow[t]{2}{*}{$\begin{array}{l}\text { PAS2 } \\
\text { Area }\end{array}$} & \multicolumn{2}{|c|}{ PAS-3 } & \multirow[t]{2}{*}{$\begin{array}{l}\text { PAS3 } \\
\text { Area }\end{array}$} & \multirow[t]{2}{*}{$\chi^{2}$} & \multirow[t]{2}{*}{ df } & \multirow[t]{2}{*}{$P$-value } \\
\hline & & & & $\mathrm{O}$ & E & & $\mathrm{O}$ & $\mathrm{E}$ & & $\mathrm{O}$ & E & & $\mathrm{O}$ & $\mathrm{E}$ & & & & \\
\hline \multirow{6}{*}{1999} & $26 \mathrm{Mar}-8 \mathrm{Apr}$ & 93 & 1031 & & & & 13 & 23 & 0.24 & 70 & 57 & 0.61 & 10 & 14 & 0.15 & 8.149 & 2 & .017 \\
\hline & 9 Apr-22 Apr & 124 & 1308 & 1 & 1 & 0.01 & 25 & 36 & 0.29 & 84 & 72 & 0.58 & 14 & 15 & 0.12 & 5.461 & 3 & .141 \\
\hline & 23 Apr-6 May & 127 & 1354 & 2 & 4 & 0.03 & 35 & 31 & 0.24 & 76 & 71 & 0.56 & 14 & 21 & 0.16 & 4.045 & 3 & .257 \\
\hline & 7 May-20 May & 47 & 1113 & & & & 11 & 8 & 0.16 & 28 & 30 & 0.63 & 8 & 10 & 0.21 & 1.987 & 2 & .370 \\
\hline & 21 May-3 Jun & 126 & 2325 & 4 & 8 & 0.06 & 79 & 79 & 0.63 & 43 & 39 & 0.31 & 0 & 1 & 0.01 & 3.009 & 3 & .390 \\
\hline & 4 Jun-17 Jun & 40 & 1392 & & & & 0 & 0 & 0.001 & 2 & 4 & 0.10 & 38 & 36 & 0.90 & 1.121 & 2 & .571 \\
\hline \multirow{6}{*}{2000} & 25 Mar-7 Apr & 79 & 815 & & & 0.004 & 12 & 27 & 0.34 & 47 & 37 & 0.47 & 20 & 15 & 0.19 & 12.682 & 2 & .005 \\
\hline & 8 Apr-21 Apr & 66 & 1117 & & & & 8 & 20 & 0.31 & 32 & 32 & 0.49 & 26 & 13 & 0.20 & 20.011 & 2 & $<.001$ \\
\hline & 22 Apr-5 May & 145 & 1423 & & & & 8 & 18 & 0.12 & 96 & 93 & 0.64 & 41 & 34 & 0.24 & 6.733 & 2 & .035 \\
\hline & 6 May-19 May & 112 & 2494 & & & & 6 & 12 & 0.11 & 52 & 50 & 0.45 & 54 & 50 & 0.44 & 3.531 & 2 & .171 \\
\hline & 20 May-3 Jun & 77 & 2166 & & & & 3 & 9 & 0.12 & 6 & 16 & 0.20 & 68 & 52 & 0.68 & 15.109 & 2 & .001 \\
\hline & 4 Jun-16 Jun & 121 & 2107 & & & & 2 & 10 & 0.08 & 9 & 26 & 0.21 & 110 & 85 & 0.70 & 24.888 & 2 & $<.001$ \\
\hline \multirow{5}{*}{2001} & 6 Apr-19 Apr & 31 & 784 & & & & 8 & 10 & 0.33 & 23 & 21 & 0.67 & & & & 0.661 & 1 & .416 \\
\hline & 20 Apr-3 May & 117 & 1667 & 9 & 12 & 0.11 & 29 & 31 & 0.27 & 79 & 70 & 0.60 & 0 & 3 & 0.03 & 5.555 & 3 & .135 \\
\hline & 4 May-17 May & 62 & 2027 & & & 0.002 & 3 & 9 & 0.15 & 32 & 31 & 0.50 & 27 & 22 & 0.35 & 5.541 & 2 & .136 \\
\hline & 18 May-31 May & 119 & 2249 & & & & 1 & 8 & 0.07 & 61 & 63 & 0.53 & 57 & 48 & 0.40 & 7.921 & 2 & .019 \\
\hline & 15 Jun-28 Jun & 58 & 2183 & & & & 0 & 1 & 0.02 & 7 & 8 & 0.14 & 51 & 49 & 0.85 & 1.142 & 2 & .565 \\
\hline
\end{tabular}

In 2000 and 2001, elk distributions were associated with greener locations for all time intervals (Table 1). Elk distributions in PAS-2 for 2000 differed from expected values and ranged from 57\% (25 Mar-8 Apr) more observations than expected to $79 \%$ (20 May-3 Jun) fewer observations than expected. Recorded elk observations in PAS-3 for 2000 exceeded expected values for all images and ranged from $74 \%$ (6-19 May) to $271 \%$ (8-21 April). Elk distributions in PAS-2 for 2001 differed from expected values and ranged from 92\% (6-19 Apr) more observations than expected to $59 \%$ (15-28 Jun) fewer observations than expected. In 2001, elk observations in PAS-3 exceeded those expected by chance for all images and ranged from 78\% (18-31 May) to $108 \%$ (4-17 May). The AVHRR image 1-14 June 2001 was not included in the analysis because no elk locations were obtained during that time interval. NPAS categories comprised no more than $15 \%$ (25 March-7 April 2000) of the Chi-square test values for all 3 years. Nonphotosynthetically active surfaces typically ceased to comprise any detectable portion of the landscape at varying times later in the spring. A trend of increasing proportions of elk observations when compared among consecutive image dates was apparent for the most photosynthetically active areas, PAS-3. Although areal proportions of PAS-3 continued to increase throughout spring, elk were consistently observed in them at greater numbers than would be expected by chance (Table 1 ).

Four of 17 independent Chi-square tests, all in 2000, associated elk distribution with greener areas when compared with the small analysis area (Table 2). No significant independent Chi-square tests were estimated for 1999 and 2001. The small analysis areas ranged from 784 to $2,494 \mathrm{~km}^{2}$ $\left(\bar{x}=1,621 \mathrm{~km}^{2}\right.$, S.E. $\left.=137 \mathrm{~km}^{2}\right)$ and varied with changes in image date range and number and distribution of elk locations (Table 2). Frequency of occurrence for NPAS was less among years in the small analysis areas when compared with the Analysis Area used in Table 1. Differences between observed and expected values during spring 2000 occurred early and late in the season. During 2000, less than half the expected elk observations were made on PAS- 1 areas during the 25 March-7 April interval. Twenty-seven percent more elk were observed in PAS-2 and 33\% more elk were observed in PAS-3 areas than expected (Table 2). Elk observations during 8-21 April $(P<.001)$ were twice the expected numbers for PAS-3 areas. During 20 May-3 June and 4-16 June, $31 \%$ and $29 \%$ more elk, respectively, were observed on PAS-3 areas than expected. By the last spring time period in each year, PAS-3 comprised at least $70 \%$ of the small analysis area (Table 2).

\section{Discussion}

Spring distributions of elk in the study area were closely associated with portions of the landscape exhibiting relatively greater photosynthetic activity (spring green-up). As elk leave the winter range during spring migration they typically move west to higher elevations [52] in association with 
greenwave. Snow accumulation and snow depths that doubled in early April 1999 [54] influenced vegetation phenology and affected distribution of elk. Sweeney [1] concluded that spring migration was more strongly associated with vegetation greenness than receding snowline for elk in southcentral Colorado. He further concluded that late snowfall during spring may inhibit movements of a portion of the wintering herd. Temporal and spatial variation in climatic conditions $[32,34]$, snow coverage and soil temperature [29], and soil moisture [69] influence vegetation phenology and subsequent NDVI greenness values [70]. Onset and extent of green-up may have been inhibited by minimal snowpack during some winters, timing of spring snows, and subsequent precipitation events. Elk exploited greener areas late in spring 1999 responding to increased photosynthetic activity following precipitation events known to influence plant phenology [42, 43].

In 2000 and 2001, elk were consistently associated with greener portions of the landscape. The PAS-3 category represented a greater proportion of the landscape earlier in the spring than in 1999 (Table 1). Timing and amounts of snowfall were greater in these 2 years [54] than in 1999, possibly explaining differences among years. Variation in elk distributions associated with greener areas may be explained by environmental stochasticity. Multiple interacting factors directly or indirectly influenced elk temporospatial distribution. Precipitation, photoperiod, soil moisture, temperature $[34,35,40,42,43,69-72]$, and snow melt [73, 74] influence vegetation phenological stage and timing of plant emergence. Topography and associated elements such as elevation, slope, and aspect affect these factors adding greater complexity to vegetation response. Effects of many of these factors are subtle or difficult to quantify particularly in relation to their influence on animal behavior. However, factors such as snow depth often play dominant roles in elk movement [9]. Mountain lions (Puma concolor), black bears (Ursus americanus), and coyotes (Canis latrans) that occur in this area did not likely play a role in elk distributions. If predator displacement of elk occurred, it would have been at a finer spatial scale than our data would be capable of detecting.

Elk in the study area appeared to associate with greener portions of the landscape in years when precipitation more closely followed the long-term average [54]. NDVI greenness values are closely associated with cumulative precipitation estimates $[40,42,43]$. Variation in timing and extent of precipitation may have influenced observed differences in greenwave among years. Spring migration occurs when vegetation is in early stages of growth and in association with retreating snowline $[1,2,4-6]$. Elk benefit by exploiting emergent vegetation $[27,75]$ while traveling to higher elevations allowing individuals to select plant species at phenological stages when digestibility and protein levels are high [17]. Variable rates of snowmelt influence timing of emergence and plant phenological stage $[73,74]$. Nutritional characteristics $[19,76]$ of spring vegetation may be particularly important to ungulates experiencing increased nutritional demands during late gestation and lactation [23, $24,76]$. One exception is in those areas where quantity is consistently limiting, such as arctic vegetation communities [77].

Investigation into higher order habitat selection [68] within the small analysis areas proved inconclusive. Elk distributions were not associated with greener locations in the small analysis areas. While AVHRR data were sufficient to compare elk distribution to greener locations in the Analysis Area $\left(5,912 \mathrm{~km}^{2}\right)$, their nominal spatial resolution $\left(1 \mathrm{~km}^{2}\right)$ may not have been adequate to examine elk distributions with greener locations at the finer geographic scale of the smaller analysis areas. Therefore, we were unable to adequately address higher-order habitat selection [68] using the small analysis areas. Using remote sensing data with higher spatial resolution than AVHRR, such as MODIS, may have allowed us to better characterize elk behavior in relation to vegetation greenness within the small analysis areas.

\section{Management Implications}

Management decisions should be made with an explicit recognition of substantial temporospatial variation in spring elk distributions. Variations in elk distributions result from complex interactions among multiple variables including climatic conditions, vegetation community types, plant phenology, predation, and land use practices. Habitat manipulation that accounts for elk response to temporal and spatial variability in vegetation dynamics may be used to mitigate human-wildlife interactions. Management that improves quantity of high-value spring forages or improves forage quality would benefit elk and could be used to modify elk distributions that reduce potential resource conflicts on private lands and help meet multiple-use management objectives on public lands. Other considerations in addressing management challenges include the spatial scale of management activities, vegetation monitoring, evaluation of elk performance, and human satisfaction.

\section{Acknowledgments}

The authors thank M. Bleiweiss, S. Schrader, and A. Ernst for assistance in acquisition and processing of AVHRR data. Pilot C. Stansell was instrumental in locating elk. D. Cram reviewed earlier versions of this paper.

\section{References}

[1] J. M. Sweeney, Elk movements and calving as related to snow cover, dissertation, Colorado State University, Fort Collins, Colo, USA, 1975.

[2] J. M. Sweeney and J. R. Sweeney, "Snow depths influencing winter movements of elk," Journal of Mammalogy, vol. 65, pp. 524-526, 1984.

[3] A. W. Adams, "Migration," in Elk of North America, Ecology and Management, J. W. Thomas and D. E. Toweill, Eds., pp. 301-321, Stackpole Books, Harrisburg, Pa, USA, 1982.

[4] M. S. Boyce, "Migratory behavior and management of elk (Cervus elaphus)," Applied Animal Behaviour Science, vol. 29, no. 1-4, pp. 239-250, 1991. 
[5] O. J. Murie, The Elk of North America, The Stackpole, Harrisburg, Pa, USA, 1951.

[6] A. R. Brazda, "Elk migration patterns and some of the factors affecting movements in the Gallatin River drainage, Montana," Journal of Wildlife Management, vol. 17, pp. 9-23, 1953.

[7] J. Madsen, The Elk, Conservation Department, WinchesterWestern Div., Olin Corporation, East Alton, Ill, USA, 1966.

[8] P. D. Dalke, R. D. Beemand, F. J. Kindel, R. J. Robel, and T. R. Williams, "Seasonal movements of elk in the Selway River Drainage, Idaho," Journal of Wildlife Management, vol. 29, pp. 333-338, 1965.

[9] D. R. McCullough, "Long range movements of large terrestrial mammals," in Migration: Mechanisms and Adaptive Science, M. A. Rankin, Ed., vol. 27 of Contributions in Marine Science, pp. 444-465, Marine Science Institute, University of Texas, Austin, Tex, USA, 1985.

[10] M. Hebblewhite, E. Merrill, and G. McDermid, "A multiscale test of the forage maturation hypothesis in a partially migratory ungulate population," Ecological Monographs, vol. 78, no. 2, pp. 141-166, 2008.

[11] R. M. Holdo, R. D. Holt, and J. M. Fryxell, "Opposing rainfall and plant nutritional gradients best explain the wildebeest migration in the Serengeti," American Naturalist, vol. 173, no. 4, pp. 431-445, 2009.

[12] M. Hebblewhite and E. H. Merrill, "Multiscale wolf predation risk for elk: does migration reduce risk?” Oecologia, vol. 152, no. 2, pp. 377-387, 2007.

[13] J. L. Frair, E. H. Merrill, D. R. Visscher, D. Fortin, H. L. Beyer, and J. M. Morales, "Scales of movement by elk (Cervus elaphus) in response to heterogeneity in forage resources and predation risk," Landscape Ecology, vol. 20, no. 3, pp. 273-287, 2005.

[14] D. Fortin, H. L. Beyer, M. S. Boyce, D. W. Smith, T. Duchesne, and J. S. Mao, "Wolves influence elk movements: behavior shapes a trophic cascade in Yellowstone National Park," Ecology, vol. 86, no. 5, pp. 1320-1330, 2005.

[15] A. M. Kittle, J. M. Fryxell, G. E. Desy, and J. Hamr, "The scaledependent impact of wolf predation risk on resource selection by three sympatric ungulates," Oecologia, vol. 157, no. 1, pp. 163-175, 2008.

[16] J. M. Fryxell, "Forage quality and aggregation by large herbivores," American Naturalist, vol. 138, no. 2, pp. 478-498, 1991.

[17] S. D. Albon and R. Langvatn, "Plant phenology and the benefits of migration in a temperate ungulate," Oikos, vol. 65, no. 3, pp. 502-513, 1992.

[18] J. V. Gedir and R. J. Hudson, "Seasonal foraging behavioural compensation in reproductive wapiti hinds (Cervus elaphus canadensis)," Applied Animal Behaviour Science, vol. 67, no. 12, pp. 137-150, 2000.

[19] A. Mysterud, R. Langvatn, N. G. Yoccoz, and N. C. Stenseth, "Plant phenology, migration and geographical variation in body weight of a large herbivore: the effect of a variable topography," Journal of Animal Ecology, vol. 70, no. 6, pp. 915923, 2001.

[20] V. Geist, "Adaptive behavioral strategies," in Elk of North America: Ecology and Management, J. W. Thomas and D. E. Toweill, Eds., pp. 219-277, Stackpole Books, Harrisburg, Pa, USA, 1982.

[21] R. R. Hofmann, "Digestive physiology of the deer-their morphophysiological specialisation and adaptation," The Royal Society of New Zealand Bulletin, vol. 22, pp. 393-407, 1985.
[22] J.-M. Gaillard, M. Festa-Bianchet, N. G. Yoccoz, A. Loison, and C. Toïgo, "Temporal variation in fitness components and population dynamics of large herbivores," Annual Review of Ecology and Systematics, vol. 31, pp. 367-393, 2000.

[23] J. G. Cook, "Nutrition and food," in North American Elk: Ecology and Management, D. E. Toweill and J. W. Thomas, Eds., pp. 259-349, Smithsonian Institution Press, Washington, DC, USA, 2002.

[24] J. G. Cook, B. K. Johnson, R. C. Cook, et al., "Effects of summer-autumn nutrition and parturition date on reproduction and survival of elk," Wildlife Monograms, vol. 155, pp. 161, 2004.

[25] J. R. Piaseke, Relationships among condition, health, and reproduction in free-ranging elk (Cervus elaphus) populations throughout the United States, Ph.D. thesis, New Mexico State University, Las Cruces, NM, USA, 2006.

[26] L. C. Bender and J. G. Cook, "Nutritional condition of elk in rocky mountain national park," Western North American Naturalist, vol. 65, no. 3, pp. 329-334, 2005.

[27] M. W. Alldredge, J. M. Peek, and W. A. Wall, "Nutritional quality of forages used by elk in northern Idaho," Journal of Range Management, vol. 55, no. 3, pp. 253-259, 2002.

[28] M. D. Schwartz and B. C. Reed, "Surface phenology and satellite sensor-derived onset of greenness: an initial comparison," International Journal of Remote Sensing, vol. 20, no. 17, pp. 3451-3457, 1999.

[29] M. D. Schwartz, "Phenology and springtime surface-layer change," Monthly Weather Review, vol. 120, pp. 2570-2578, 1992.

[30] C. F. Jordan, "Derivation of leaf-area index from quality of light on the forest floor," Ecology, vol. 50, pp. 663-666, 1969.

[31] J. W. Rouse Jr., R. H. Haas, J. A. Schell, and D. W. Deering, "Monitoring vegetation systems in the Great Plains with ERTS," in Proceedings of the 3rd Earth Resources Technology Satellite-1 Symposium, pp. 309-317, Greenbelt, Md, USA, 1974.

[32] S. N. Goward, C. J. Tucker, and D. G. Dye, "North American vegetation patterns observed with the NOAA-7 advanced very high resolution radiometer," Vegetatio, vol. 64, pp. 3-14, 1985.

[33] S. N. Goward, D. Dye, A. Kerber, and V. Kalb, "Comparison of North and South American biomes from AVHRR observations," Geocarto International, vol. 1, pp. 27-39, 1987.

[34] C. O. Justice, B. N. Holben, and M. D. Gwynne, "Monitoring East African vegetation using AVHRR data," International Journal of Remote Sensing, vol. 7, no. 11, pp. 1453-1474, 1986.

[35] B. C. Reed, J. F. Brown, D. VanderZee, T. R. Loveland, J. W. Merchant, and D. O. Ohlen, "Measuring phenological variability from satellite imagery," Journal of Vegetation Science, vol. 5, no. 5, pp. 703-714, 1994.

[36] C. J. Markon, M. D. Fleming, and E. F. Binnian, "Characteristics of vegetation phenology over the Alaskan landscape using AVHRR time-series data," Polar Record, vol. 31, no. 177, pp. 179-190, 1995.

[37] X. Chen, Z. Tan, M. D. Schwartz, and C. Xu, "Determining the growing season of land vegetation on the basis of plant phenology and satellite data in Northern China," International Journal of Biometeorology, vol. 44, no. 2, pp. 97-101, 2000.

[38] A. Lobo, J. J. Ibáñez Martí, and C. C. Giménez-Cassina, "Regional scale hierarchical classification of temporal series of AVHRR vegetation index," International Journal of Remote Sensing, vol. 18, no. 15, pp. 3167-3193, 1997. 
[39] J. T. Al-Bakri and J. C. Taylor, "Application of NOAA AVHRR for monitoring vegetation conditions and biomass in Jordan," Journal of Arid Environments, vol. 54, no. 3, pp. 579-593, 2003.

[40] M. Karabulut, "An examination of relationships between vegetation and rainfall using maximum value composite AVHRR-NDVI data," Turkish Journal of Botany, vol. 27, no. 2, pp. 93-101, 2003.

[41] S. Hamel, M. Garel, M. Festa-Bianchet, J.-M. Gaillard, and S. D. Côté, "Spring Normalized Difference Vegetation Index (NDVI) predicts annual variation in timing of peak faecal crude protein in mountain ungulates," Journal of Applied Ecology, vol. 46, no. 3, pp. 582-589, 2009.

[42] J. Cihlar, L. St.-Laurent, and J. A. Dyer, "Relation between the normalized difference vegetation index and ecological variables," Remote Sensing of Environment, vol. 35, no. 2-3, pp. 279-298, 1991.

[43] L. Ji and A. J. Peters, "Assessing vegetation response to drought in the northern Great Plains using vegetation and drought indices," Remote Sensing of Environment, vol. 87, no. 1, pp. 8598, 2003.

[44] P. K. Coe, B. K. Johnson, J. W. Kern, S. L. Findholt, J. G. Kie, and M. J. Wisdom, "Responses of elk and mule deer to cattle in summer," Journal of Range Management, vol. 54, pp. A51-A76, 2001.

[45] N. T. Hobbs, D. L. Baker, G. D. Bear, and D. C. Bowden, "Ungulate grazing in sagebrush grassland: mechanisms of resource competition," Ecological Applications, vol. 6, no. 1, pp. 200-217, 1996.

[46] U. S. Department of Agriculture, Terrestrial Ecosystem Survey of the Carson National Forest, Forest Service. Southwestern Region, U.S. Government Printing Office, Washington, DC, USA, 1987.

[47] National Climate Data Center, "Data for Brazos Lodge, Cerro, Chama, Manassa, and Tres Piedras weather stations," NCDC, March 2003, http://www.ncdc.noaa.gov/oa/ncdc.html.

[48] W. A. Dick-Peddie, New Mexico Vegetation: Past, Present, and Future, University of New Mexico Press, Albuquerque, NM, USA, 1993.

[49] D. E. Brown, "Great basin conifer woodland and plains and great basin grasslands," in Biotic Communities of the Southwestern United States and Northwestern Mexico, D. E. Brown, Ed., pp. 52-57 and 115-121, University of Utah Press, Salt Lake City, Utah, USA, 1994.

[50] C. P. Pace and D. E. Brown, "Rocky mountain and madrean montane conifer forests," in Biotic Communities of the Southwestern United States and Northwestern Mexico, D. E. Brown, Ed., pp. 43-48, University of Utah Press, Salt Lake City, Utah, USA, 1994.

[51] D. A. Jessup, R. K. Clark, R. A. Weaver, and M. D. Kock, "The safety and cost effectiveness of net-gun capture of desert bighorn sheep (Ovis canadensis nelsoni)," Journal of Zoo Animal Medicine, vol. 19, pp. 208-213, 1988.

[52] S. T. Smallidge, B. C. Thompson, W. R. Gould, L. E. Kantar, U. A. Rosauer, and R. A. Deitner, "Demographics, temporal and spatial dynamics, and resource conflict evaluation of elk wintering near San Antonio Mountain in northcentral New Mexico," Final Report Federal Aid Project W-136-R, New Mexico Department of Game and Fish, Santa Fe, NM, USA, 2003.

[53] S. Harris, W. J. Cresswell, P. G. Forde, W. J. Trewhella, T. Woollard, and S. Wray, "Home-range analysis using radio-tracking data-a review of problems and techniques particularly as applied to the study of mammals," Mammal Review, vol. 20, no. 2-3, pp. 97-123, 1990.

[54] S. T. Smallidge, Temporospatial distribution of a northcentral New Mexico elk herd in relation to spring vegetation greenness values, vulnerability to harvest, and public land grazing, dissertation, New Mexico State University, Las Cruces, NM, USA, 2005.

[55] B. N. Holben, "Characteristics of maximum-value composite images from temporal AVHRR data," International Journal of Remote Sensing, vol. 7, no. 11, pp. 1417-1434, 1986.

[56] J. C. Eidenshink, "The 1990 conterminous US AVHRR data set," Photogrammetric Engineering \& Remote Sensing, vol. 58, no. 6, pp. 809-813, 1992.

[57] J. P. Malingreau, "Global vegetation dynamics: satellite observations over Asia," International Journal of Remote Sensing, vol. 7, no. 9, pp. 1121-1146, 1986.

[58] D. Lloyd, "A phenological classification of terrestrial vegetation cover using shortwave vegetation index imagery," International Journal of Remote Sensing, vol. 11, no. 12, pp. 2269-2279, 1990.

[59] T. R. Loveland, J. W. Merchant, D. O. Ohlen, and J. F. Brown, "Development of a land-cover characteristics database for the conterminous US," Photogrammetric Engineering \& Remote Sensing, vol. 57, no. 11, pp. 1453-1463, 1991.

[60] Environmental Systems Research Institute (ESRI), ArcView version 3.2a, ESRI, Redlands, Calif, USA, 1998.

[61] S. A. McClean, M. A. Rumble, R. M. King, and W. L. Baker, "Evaluation of resource selection methods with different definitions of availability," Journal of Wildlife Management, vol. 62, no. 2, pp. 793-801, 1998.

[62] ERDAS, ERDAS Imagine version 8.6, Leica Geosystems, St. Gallen, Switzerland, 2002.

[63] Environmental Systems Research Institute (ESRI), ArcView version 3.3, ESRI, Redlands, Calif, USA, 2002.

[64] Environmental Systems Research Institute (ESRI), ArcGIS version 9.0, ESRI, Redlands, Calif, USA, 2004.

[65] J. H. Zar, Biostatistical Analysis, Prentice Hall, Upper Saddle River, NJ, USA, 3rd edition, 1996.

[66] R. O. Kuehl, Design of Experiments: Statistical Principles of Research Design and Analysis, Duxbury Press, Pacific Grove, Calif, USA, 2nd edition, 2000.

[67] W. G. Cochran, "Some methods for strengthening the common $\chi^{2}$ tests," Biometrics, vol. 10, pp. 417-451, 1954.

[68] D. H. Johnson, "The comparison of usage and availability measurement for evaluating resource preference," Ecology, vol. 61, pp. 65-71, 1980.

[69] F. Yu, K. P. Price, J. Ellis, and P. Shi, "Response of seasonal vegetation development to climatic variations in eastern central Asia," Remote Sensing of Environment, vol. 87, no. 1, pp. 42-54, 2003.

[70] R. Lee, F. Yu, K. P. Price, J. Ellis, and P. Shi, "Evaluating vegetation phenological patterns in Inner Mongolia using NDVI time-series analysis," International Journal of Remote Sensing, vol. 23, no. 12, pp. 2505-2512, 2002.

[71] A. R. Malo and S. E. Nicholson, "A study of rainfall and vegetation dynamics in the African Sahel using normalized difference vegetation index," Journal of Arid Environments, vol. 19, no. 1, pp. 1-24, 1990.

[72] M. A. White, P. E. Thornton, and S. W. Running, "A continental phenology model for monitoring vegetation responses to interannual climatic variability," Global Biogeochemical Cycles, vol. 11, no. 2, pp. 217-234, 1997. 
[73] M. D. Schwartz and T. R. Karl, "Spring phenology: nature's experiment to detect the effect of "green-up" on surface maximum temperatures," Monthly Weather Review, vol. 118, no. 4, pp. 883-890, 1990.

[74] C. Galen and M. L. Stanton, "Responses of snowbird plant species to changes in growing-season length," Ecology, vol. 76, no. 5, pp. 1546-1557, 1995.

[75] L. E. Morgantini and R. J. Hudson, "Nutritional significance of wapiti (Cervus elaphus) migrations to alpine ranges in western Alberta, Canada," Arctic \& Alpine Research, vol. 21, no. 3, pp. 288-295, 1989.

[76] N. E. Walsh, T. R. McCabe, J. M. Welker, and A. N. Parsons, "Experimental manipulations of snow-depth: effects on nutrient content of caribou forage," Global Change Biology, vol. 3, no. 1, pp. 158-164, 1997.

[77] R. Van der Wal, N. Madan, S. van Lieshout, C. Dormann, R. Langvatn, and S. D. Albon, "Trading forage quality for quantity? Plant phenology and patch choice by Svalbard reindeer," Oecologia, vol. 123, no. 1, pp. 108-115, 2000. 

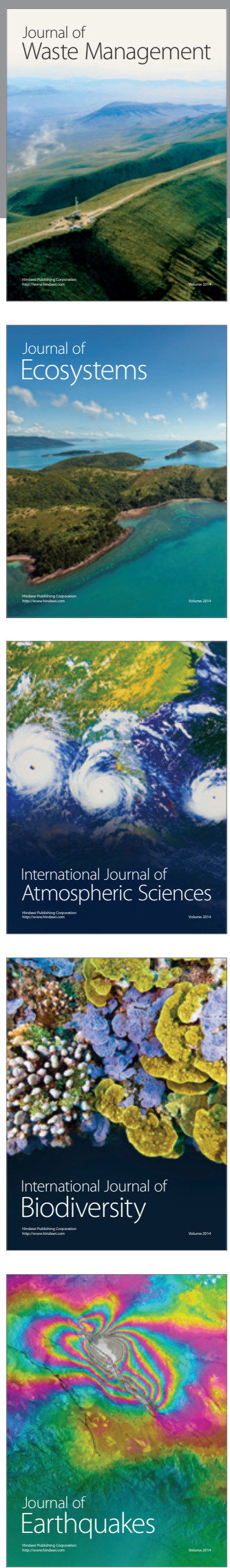
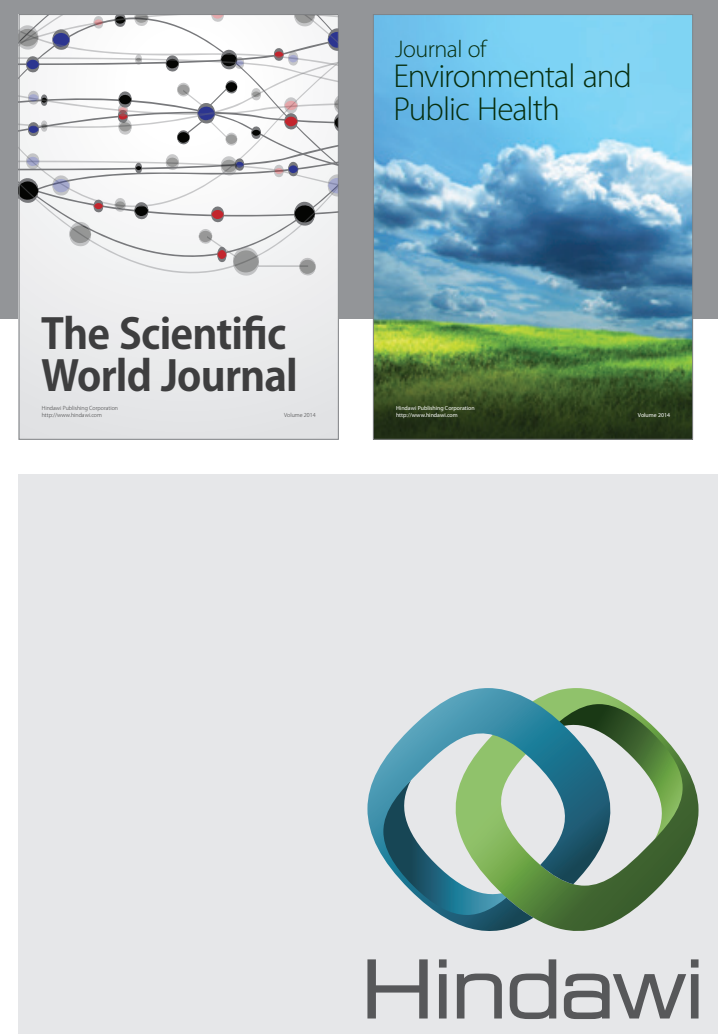

Submit your manuscripts at

http://www.hindawi.com
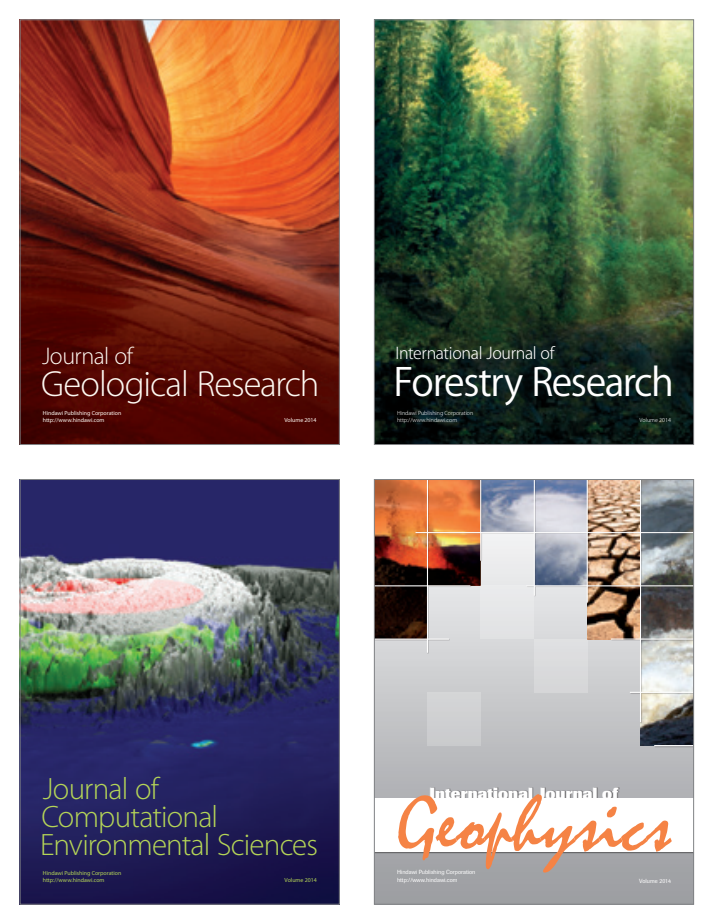
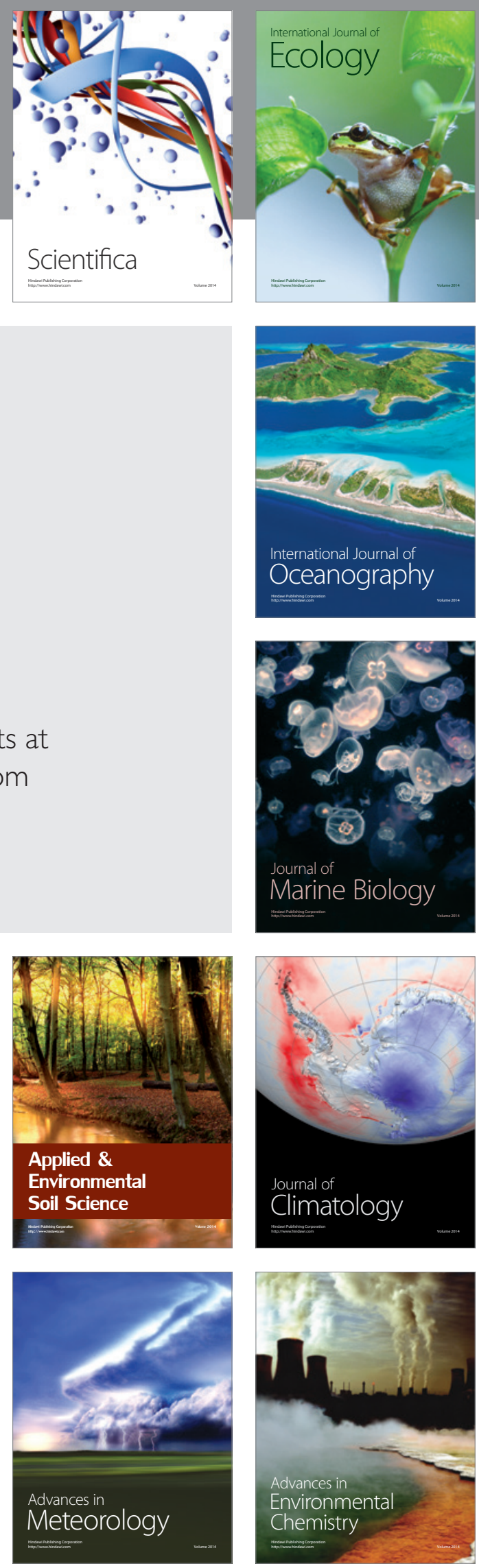